\title{
The technology of improving almond planting material tolerance to the salt stresses of soils based on experience in phytotron
}

\author{
Antar Badran ${ }^{1,2}$, and Igor Savin ${ }^{2,3 *}$, \\ ${ }^{1}$ Desert Research Centre, 11753 Cairo, Egypt \\ ${ }^{2}$ RUDN University, Faculty of Ecology, 115093 Moscow, Russia \\ ${ }^{3}$ V.V. Dokuchaev Soil Science Institute, 119017 Moscow, Russia
}

\begin{abstract}
There was studied impact of the bitter almond seeds preliminary steeping on the development of plants at the first stages of development in conditions of saline waters irrigation in the greenhouse experiment ambient in phytotron. It was established that steeping the seeds in excessive salt solution results in enhanced plants tolerance to the soil salinization and saline waters irrigation. This is evidenced by the obtained regularities of influence on the development of plants of biochemical character (content of proline, chlorophyll and carotinoids, total carbon); chemical (content of basic chemical elements); morphological (rate of the plants height and stalk diameter growth, leaf-area duration). The introduction of developed technology into nursery science will permit to improve the tolerance of seedlings to salinization of soils and irrigation waters.
\end{abstract}

\section{Introduction}

Bitter almond (Prunus Amygdalus) is widely used in Egypt as a parent stock for stone fruits [1]. At the present time the areas under this culture in the country occupy about 40 thousand hectares, which amounts to about 6 percent of total area, occupied by the fruit cultures in Egypt.

In many cases almond is cultivated on the areas, the soils of which are reclamated. The soils of these grounds feature the variously pronounced residual salinization [2,3]. More over, the culture is cultivated in irrigated conditions. The irrigation waters are also frequently salinated.

The salinization of soils and irrigation waters is known to be able to decrease the indices of many fruit trees productivity and growth [4,5]. Bitter almond is also sensitive to salinization [6,7]. But the influence of salinization on the initial stages of bitter almond growth and its tolerance is underinvestigated up to the present.

The proposed paper bears the results of experiments to make known the peculiarities of the soils and irrigation waters salinization influence on the first development stages of bitter almond, the seeds of which were preliminarily steeped in saline solution.

\footnotetext{
*Corresponding author: savin iyu@esoil.ru
} 


\section{Object and Methods}

To perform the experiment the seed material, got from Egypt, was used. The seeds of almond were steeped during 48 hours in $\mathrm{NaCl}$ solution having concentration of 1,3 and $51 \mathrm{dSm}^{-1}$, that is equivalent, respectively, to 640,1920 and $3200 \mathrm{ppm}$ [8]. These concentrations were used, taking into consideration the peculiarities of the bitter almond tolerance to salinization [9]. The solution was renewed every day to remove the influence of the growth-inhibiting substances.

As the seeds were steeped, they were stratified at the temperature of $+6^{\circ} \mathrm{C}$ over a period of eight weeks (cold stratification). Thereafter the ungerminated seeds were exposed to the temperature of $+22^{\circ} \mathrm{C}$ during three weeks to stimulate their germination.

As they germinated, three plants of each variant were bedded out into polyethylene packs of $15 \times 20 \mathrm{~cm}$ in size, containing a mixture of turf and perlite

The transplant seedlings were grown at the temperature of $25 \pm 2^{\circ} \mathrm{C}$, alternating 16 hours of illumination (with intensity of $500-700 \mu \mathrm{M} \mathrm{m}^{-2} \mathrm{~s}^{-1}$ ) and 8 hours of darkness. The irrigation was carried out, as the circumstances required, once a week by solution with content of salt of $5 \mathrm{dSm}^{-1}$.

The parameters of plants were measured and calculated as follows:

1. The gain in stalk diameter $(\mathrm{mm})$ (with the use of sliding calipers).

2. The gain in plants height $(\mathrm{cm})$.

3. The leaf-area duration (sq. $\mathrm{cm}$ ) and number of leaves per single plant.

4. The dry matter percentage in leaves.

5. The content of pigments (chlorophyll $\mathrm{a}, \mathrm{b}$ and carotinoids) $(\mathrm{mg} / \mathrm{g})$ was determined following the method, described in [10].

6 . The content of proline was estimated according to [11].

7. The extraction of hydrocarbons $(\mathrm{mg} / \mathrm{g}$ of dry matter) involved a phenol-sulphuric-acid process.

8. Nitrogen in the leaves was determined following "The methodological instructive regulations to determine alkali-hydrolyzable nitrogen in soil according to the method of Cornfield" (1985).

The obtained results were statistically processed using the analysis of variance (ANOVA) in MSTAT package. The pair-wise comparison of mean values was conducted by the least significant difference (LSD).

\section{Results and Discussion}

The seedlings, germinated from the seeds, which were steeped in the high-salt concentration solution $\left(5 \mathrm{dsm}^{-1}\right)$, featured the larger gain in diameter and height, as compared with the treatment by solution with the lower concentration of salts (Table 1). They showed the higher adaptation to the salt stress in germination period and ability to tolerate it after field setting. It corresponds on the whole to the earlier obtained results for other cultures [12].

The preplanting steeping of the bitter almond seeds in the high-salt concentration solution resulted in the larger number of leaves on a plant. By and large, the similar tendency is observed not only in the case of bitter almond [13].

The area of plant leaves practically was not dependent on the concentration of salt solution, but the dry mass of plants increased a bit with the higher concentration of salt solution, in which the seeds were steeped (Table1).

The plants, the seeds of which were steeped in the high-salt concentration solution, featured also the higher content of chlorophyll and carotinoids.

The increased content of proline may be also connected with attempt of plants to tolerate the hyperosmotic stress, caused by salinization [14]. In our situation steeping the seeds in 
higher-salt concentration solution resulted consequently in its lower content in a plant, which is an evidence of its higher-salt tolerance.

Steeping the seeds in the higher-salt concentration solution improved on the whole the vegetative growth, brought to increase in the quantity of leaves, their area and, as a result of it, to their higher content of chlorophyll, which promoted the higher rate of photosynthesis and the consequent accumulation of the larger quantity of hydrocarbons in the plants (Table 1). The similar processes were noted for other plants and by other investigators [15].

The results we obtained showed that the largest values of nitrogen and phosphorus content in the leaves of plants were also obtained in the variant with steeping the seeds before planting in solution with $5 \mathrm{dsm}^{-1}$ concentration of salt (Table2).

The largest rate of $\mathrm{K}^{+}, \mathrm{Ca}^{2+}$ and $\mathrm{Mg}^{2+}$ ions retention by the plants was also revealed in germinants from the seeds, which were steeped in solution with the maximum concentration of salt.

It is known that $\mathrm{Na}^{+}$ions on salinated soils compete with $\mathrm{K}^{+}$ions in the process of retention through plasma membrane of plant cells [16]. In our experiment, the preliminary steeping of the seeds in solution with the high concentration of salts brought to the lower $\mathrm{Na}$ content in the plants, that is another evidence of the higher tolerance of plants, received from the similar seeds, to the salt stress.

Thus, practically all the analyzed indicators and obtained regularities of the bitter almond seedlings condition show the preliminary steeping of seeds in the high salts concentration solution bring consequently to the higher parent stocks and seedlings tolerance to the salt stress.

To increase the tolerance of the bitter almond seedlings to the stress on salinated soils or during the irrigation by salinated waters, it is recommended to carry out the preliminary steeping of seeds in solution with $5 \mathrm{dSm}^{-1}$ concentration of salts.

We would like to thank the Centre of collective usage of equipment of the V.V. Dokuchaev Soil Science Institute for their help with laboratory analysis of plant samples. The publication has been prepared with support of the "RUDN University Program 5-100". 
Table 1. The comparison of biometrical and biochemical values of the plants condition and development as a function of salt content in solution for steeping the seeds.

\begin{tabular}{|c|c|c|c|c|c|c|c|c|c|}
\hline \multirow{2}{*}{$\begin{array}{l}\text { Content of } \\
\text { salts in } \\
\text { solution for } \\
\text { steeping the } \\
\text { seeds }\end{array}$} & \multirow{2}{*}{$\begin{array}{l}\text { gain in } \\
\text { stalk } \\
\text { diameter } \\
(\mathrm{mm})\end{array}$} & \multirow{2}{*}{$\begin{array}{l}\text { gain in } \\
\text { height of } \\
\text { germinants } \\
(\mathrm{cm})\end{array}$} & \multirow[b]{2}{*}{$\begin{array}{c}\text { quantity of } \\
\text { leaves per } \\
\text { one plant }\end{array}$} & \multirow{2}{*}{$\begin{array}{l}\text { area of } \\
\text { leaves } \\
\text { (sq.cm) per } \\
\text { one plant }\end{array}$} & \multicolumn{5}{|c|}{ Content in leaves } \\
\hline & & & & & $\begin{array}{l}\text { chlorophyll } \\
\text { a (mg/g) }\end{array}$ & $\begin{array}{l}\text { chlorophyll } \\
\text { b (mg/g) }\end{array}$ & $\begin{array}{l}\text { carotin } \\
(\mathrm{mg} / \mathrm{g})\end{array}$ & $\begin{array}{l}\text { proline } \\
(\mathrm{mg} / \mathrm{g})\end{array}$ & $\begin{array}{c}\text { content of } \\
\text { hydrocarbons } \\
\text { in total }(\mathrm{mg} / \mathrm{g} \\
\mathrm{DW})\end{array}$ \\
\hline $1 \mathrm{dsm}^{-1}$ & 1.42 & 17.00 & 23.33 & 55.55 & 1.54 & 0.75 & 0.46 & 0.57 & 106.7 \\
\hline $3 \mathrm{dsm}^{-1}$ & 1.78 & 28.33 & 27.83 & 55.19 & 1.78 & 0.89 & 0.61 & 0.45 & 125.3 \\
\hline $5 \mathrm{dsm}^{-1}$ & 2.18 & 34.67 & 36.50 & 56.89 & 2.17 & 1.04 & 0.76 & 0.40 & 144.8 \\
\hline
\end{tabular}

Table 2. The comparison of chemical values of the plants condition and development in experiment as a function of content of salts in solution for steeping the seeds.

\begin{tabular}{|c|c|c|c|c|c|c|}
\hline \multirow{2}{*}{$\begin{array}{c}\text { content of } \\
\text { salts in } \\
\text { solution for } \\
\text { steeping the } \\
\text { seeds }\end{array}$} & $\begin{array}{c}\text { total } \\
\text { nitrogen } \\
\text { content } \\
(\%)\end{array}$ & $\begin{array}{c}\text { Total content in leaves } \\
\text { phosphorus } \\
\text { content } \\
(\mathrm{mg} / \mathrm{l})\end{array}$ & $\begin{array}{c}\text { total } \\
\text { potassium } \\
\text { content } \\
(\mathrm{mg} / \mathrm{l})\end{array}$ & $\begin{array}{c}\text { total } \\
\text { calcium } \\
\text { content } \\
(\mathrm{mg} / \mathrm{l})\end{array}$ & $\begin{array}{c}\text { total } \\
\text { magnesium } \\
\text { content } \\
(\mathrm{mg} / \mathrm{l})\end{array}$ & $\begin{array}{c}\text { total sodium } \\
\text { content }(\mathrm{g} / \mathrm{l})\end{array}$ \\
\hline $1 \mathrm{dsm}^{-1}$ & 1.27 & 7.85 & 10.87 & 21.03 & 2.30 & 8.49 \\
\hline $3 \mathrm{dsm}^{-1}$ & 1.58 & 12.23 & 13.37 & 30.65 & 2.83 & 7.56 \\
\hline $5 \mathrm{dsm}^{-1}$ & 1.87 & 17.40 & 16.87 & 39.52 & 3.26 & 6.60 \\
\hline
\end{tabular}




\section{References}

1. A. A Farag, M. A. A. Abdrabbo, M. S Abourayya, N. E Kasim, Future of Food: Journal on Food, Agriculture and Society, 5(2), 8-15, (2017). https:/www.researchgate.net/ publication/320466210_Optimizing_irrigation_requirements_for_almond trees_grown in the South_Sinai_Governorate

2. E. S. Mohamed, A. M. Ali, M. A. El Shirbeny, Afaf A. Abd El Razek, I. Yu. Savin, Eurasian Soil Science, 49(6), 632-639, (2016). https://link.springer.com/ article/10.1134\%2FS1064229316060065

3. Mohamed E., Belal A. A., Ali R.R., Saleh A., Hendawy E.A. (2019) Land Degradation. In: El-Ramady H., Alshaal T., Bakr N., Elbana T., Mohamed E., Belal AA. (eds) The Soils of Egypt. World Soils Book Series. Springer, Cham. https://doi.org/10.1007/978-3-31995516-2 9

4. M. A. Ali, R. S. El-Gendy, O. A. Ahmed, J. Hort. Sci. \& Ornamen. Plants, 5(1) , 12-21, (2013). https://www.idosi.org/jhsop/5(1)13/2.pdf

5. P. Carillo, M. G. Annunziata, G. Pontecorvo, A. Fuggi, P. Woodrow, Salinity Stress and Salt Tolerance, Abiotic Stress in Plants - Mechanisms and Adaptations, (2011). DOI: 10.5772/22331. Available from: https://www.intechopen.com/books/abiotic-stress-inplants-mechanisms-and-adaptations/salinity-stress-and-salt-tolerance

6. E. K. Nabila, M. S. Abourayya, T. S. M. Mahmoud, Bull Natl Res Cent 43, 188 (2019). https://doi.org/10.1186/s42269-019-0247-y

7. A. Momenpour, A. Imani, D. Bakhshi, E. Akbarpour, International Journal of Fruit Science, 18(4), 410-435, (2018). $\quad$ https://www.tandfonline.com/doi/full/10.1080/ $\underline{15538362.2018 .1468850}$

8. G. A. Vivaldi; S. Camposeo; G. Lopriore; C. R. Trigueros; F. P. Salcedo, Water Supply 19 (5), 1413-1421. (2019) https://doi.org/10.2166/ws.2019.008

9. C. Yücedağ, H. Cemal Gultekin, African Journal of Agricultural Research, 6, 3522-3525, (2011). https://www.researchgate.net/publication/220023089 Effects_of_cold stratification_and sowing time_on_germination_of_almond_Amygdalus_communis_L_a nd_wild_almond_Amygdalus orientalis_L_seeds

10. .B. Rakhmetov, O. M. Vergun, Ya. B. Blum, S. O. Rakhmetova, V. V. Fishchenko, Plant Introduction, 79, 83-90, (2018). http://doi.org/10.5281/zenodo.2278755

11. G. N. Shihalyeyeva, A. K.Budnyak, I. I. Shihalyeyev, O. L. Ivaschenko, Вестник Харьковского университета. Серия Биология, 21, 168-172, (2014). http://seriesbiology.univer.kharkov.ua/ukr/21(2014)/pdf/168.pdf

12. J. Mamut, D. Tan, C. C. Baskin, J. Arid Land 11, 774-784 (2019). https://doi.org/10. 1007/s40333-019-0015-8

13. R. A. Rosadi, M. Senge, D. Suhandy, A. Tusi, Journal of Agricultural Engineering and Biotechnology, (2)1, 7-12, (2014). $\quad$ https://www.researchgate.net/publication 1261215803 The Effect_of_EC_Levels_of_Nutrient_Solution_on the Growth_Yield an d Quality of Tomatoes Solanum Lycopersicum under the Hydroponic System

14. X. Liang, L. Zhang, S. K. Natarajan, D. F. Becker, Antioxid Redox Signal, 19(9), 9981011, (2013). https://doi.org/10.1089/ars.2012.5074

15. J. P. Giraldo, M. P. Landry, S. M. Faltermeier, T. P. McNicholas, N. M. Iverson, A. A. Boghossian, N. F. Reuel, A. J. Hilmer, F. Sen, J. A. Brew, Nature materials, 13(4), 400, (2014). https://www.nature.com/articles/nmat3890

16. F. J. M. Maathuis, Journal of Experimental Botany, 65(3), 849-858, (2014). https://doi.org/10.1093/jxb/ert326 